\title{
Trends in Regional Disparity in Human and Social Development in India
}

\author{
Ravindra H Dholakia
}

W.P. No. 2005-09-07

September 2005

The main objective of the working paper series of the IIMA is to help faculty members, Research Staff and Doctoral Students to speedily share their research findings with professional colleagues, and to test out their research findings at the pre-publication stage

\section{INDIAN INSTITUTE OF MANAGEMENT \\ AHMEDABAD-380 015 INDIA}




\title{
Trends in Regional Disparity in Human and Social Development in India
}

\author{
Ravindra H. Dholakia \\ I.I.M., Ahmedabad - 380015 \\ E-mail: rdholkia@,iimahd.ernet.in
}

\begin{abstract}
In the present paper, we have examined trends in regional disparity in human and social development by considering numerous indicators other than State Income. We found no support to the general impression prevailing in the recent literature that disparity is increasing over the last two decades when we subjected the trend to statistical significance test. We considered numerous output as well as the input indicators for the purpose. In very few indicators, the disparity showed an increase, whereas in a large number of indicators it either remained the same or actually declined over the last two decades. The state governments' efforts in the social sectors were perhaps a major reason for the outcome. Except education, in all other social sub-sectors, the interstate disparity in the government effort markedly declined during the 1990s compared to the 1980s. In education, it remained the same.

Our findings in this paper point to a very clear policy prescription. The social and human development is considered by all the state governments as very important and a priority sector in their development strategy. The way they are making efforts in these directions is reducing disparity across states although each state has been acting on its own. This is perhaps because of the felt need of people and the polity in states. Explicit objective of reducing regional disparity in social and human development in the central planning may not, therefore, be specially required. Augmenting the revenue resources of states allowing the states to access public borrowings directly would enable most of them to concentrate on their priority areas based on the local felt need. It is likely to address the issue of regional imbalance and disparity in a much better and efficient way without imposing excess burden since it would allow exploiting complementarities in growth and equity.
\end{abstract}




\section{Trends in Regional Disparity in Human and Social Development in India}

\section{INTRODUCTION}

India has achieved a remarkable acceleration in economic growth over the two decades and seems to be well set on the path to continue such a rapid economic growth at least in the couple of decades ahead. About a decade ago, based on a rigorous analysis of time trend of state domestic product (SDP) and identifying the years of break in the long term growth path in each state, it was found that the growth acceleration of the eighties had the regional disparity reducing impact (Dholakia, 1994). However, there have been a number of studies using varying numbers of states and length of time periods coming to different conclusions based on the methodology of interstate comparison of absolute aggregate annual SDP. (For a brief review of such studies, see Dholakia, 2003; and Misra, 2005). Pointing out inappropriateness and inadequacy of such methodologies for the Indian regional (SDP) data, it was argued that regional disparity in SDP had not significantly changed in either direction over the last two decades when proper method and measurement were used (Dholakia, 2003). Still, however, the pre-dominant view in the literature is that income disparity has increased among states in India over the last two decades and particularly over the 1990s (see for instance, the proposal note for this seminar). Moreover, it is also argued without adequate evidence that other indicators of development than SDP also show increasing disparity among states over the last two decades (Ibid.). The basic motive of the present paper is to examine this issue in detail with whatever evidence is available because it has important strategic and policy implications not only for the states, but also for the centre.

We confine our analysis in the present paper only to the development indicators other than SDP and to the spheres of human and social development over the last two decades, ie., the 1980s and the 1990s. We first take up the question of estimating a trend in regional disparity in a given indicator when the number of time points are distant and limited (Section-II). We suggest a simple and robust method. In the third section, then, we apply the method to a number of indicators of human and social development to estimate the trend in regional disparity during the last two decades in India. In the fourth section, we examine the state government efforts in terms of expenditures in social sectors and relate them to the physical inputs and output indicators. In the fifth and the final section, we summarize our findings and briefly discuss some policy implications.

\section{ESTIMATING TREND IN DISPARITY}

All the development indicators can be divided into two broad categories : (i) input indicators, and (ii) output or outcome indicators (Morris, 1978; and Archana Dholakia, 1990). Most of the input indicators are physical in nature and are represented by stocks rather than flows. The output indicators are generally subject to a physical upper and lower limits. Changes in all these indicators generally occur at a very slow speed and, therefore, they are usually measured only once in a while with a typical interval of 5 to 10 years. A continuous time series of such indicators neither is available nor would make much sense, if available. Trend in regional disparity in such indicators has therefore to be estimated by considering only two or three points.

The most popular method among researchers to examine the trend in regional disparity in such indicators is to compare the estimates of their measure of disparity at two points of time and describe the observed change in them without any statistical test of significance. The most popular measure of regional disparity at a point of time is the coefficient of variation, either unweighted or weighted by population of the regions. The only other measure sometimes used is the Gini coefficient of inequality or Lorenz ratio. In all these cases, trend in regional disparity over time is hardly ever subjected to any statistical significance test. We consider 
this as a serious limitation of the existing studies, particularly when we can find a simple solution to this problem.

Let us consider an indicator, $X$ and represent its value as $X_{j}^{t}$ for $j^{\text {th }}$ state in period t. The national value of the same indicator is represented without the sub-script $j$. At any point $t$ we can generate the 'state relatives' given by $\left(\mathrm{X}_{\mathrm{j}, /}^{\mathrm{t}} \mathrm{X}^{\mathrm{t}}\right)$ for all $\mathrm{j}$. If we consider two time points - an initial point $(\mathrm{t}=0)$ and a terminal point $(\mathrm{t}=1)$, we get two cross-sectional series of 'state relatives', $x_{j}^{1}=\left(X_{j}^{1} / X^{1}\right.$ and $x j\left(X_{j}^{0} / X^{0}\right)$. Let us consider the following crosssection regression between $\mathrm{x}_{\mathrm{j} \text { and }}^{1} \mathrm{X}_{\mathrm{j}}^{0}$ :

$\mathrm{x}_{\mathrm{j}}^{1}=\mathrm{a}+\mathrm{b} \mathrm{x}_{\mathrm{j}}^{0}+\mathrm{u}_{\mathrm{j}}$ where $\mathrm{j}=1 .$. to ...n states; and $\mathrm{u}$ is a random error.

If regional disparity in $\mathrm{X}$ has remained the same over $\mathrm{t}=0$ and $\mathrm{t}=1$, we should expect the following values of $a$ and $b$ :

$$
\mathrm{a}=0 \text { and } \mathrm{b}=1 \text {. }
$$

However, when regional disparity in $\mathrm{X}$ increases over time, we would expect that the better off states have gained further and the worse off states have lost further. Thus, $a<0$ and $b$ $>1$.

But, when regional disparity in $\mathrm{X}$ decreases over time, by the same logic, we would expect $\mathrm{a}>0$ and $\mathrm{b}<1$. Diagram 1 summarizes theses three cases.

\section{Diagram 1: Trends in Disparity.}

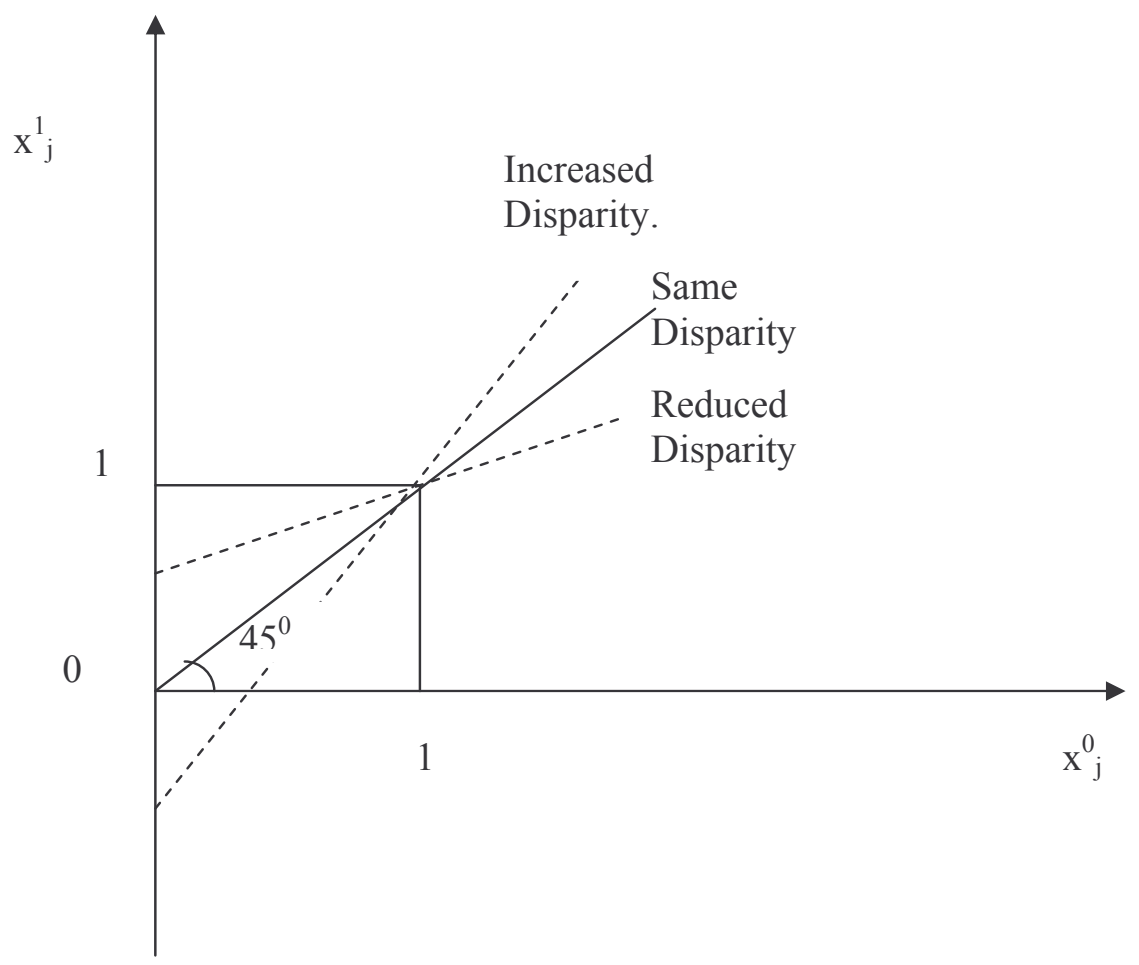

Thus, the hypotheses, to test by fitting the above regression between $x_{j}^{1}$ and $x_{j}^{0}$ are:

$$
\begin{aligned}
\mathrm{H}_{0}: & a=0 \text { and } b=1 \text { for no change in disparity } \\
\mathrm{H}_{\mathrm{A}}: & \mathrm{a}<0 \text { and } b>1 \text { for increase in disparity } \\
& \mathrm{a}>0 \text { and } \mathrm{b}<1 \text { for decrease in disparity. }
\end{aligned}
$$

This can be achieved simply by performing the standard two-tailed t-tests at the desired level of significance. 
It is interesting to point out that this statistical test and the alternative hypotheses remain the same irrespective of the nature of the indicator. Thus, even for the negatively desired indicators like infant mortality or child labour also the same tests would apply as for the positively desired indicators like literacy or life expectancy. Another advantage of the suggested method is that it provides statistical test for the trend (change) in disparity over time irrespective of the measure of absolute disparity at a point of time. As it happens in most cases, our interest is in the change (or trend) in disparity over time and not in the absolute measure of such disparities at a point.

\section{TRENDS IN VARIOUS INDICATORS}

We have considered numerous indicators of social and human development available from Planning Commission (2002) and updated them to include readily available data for the year 2001 from the Census, 2001 and the website of indiastat.com. In order to understand the trend in regional disparity in these indicators over the last two decades, we have considered three point-to-point comparisons, viz. early eighties and early nineties; early nineties and late nineties ( or 2001); and early eighties and late nineties (or 2001). All the regression results are presented for these three sub-periods for each indicator in the Appendix Table at the end.

We may first consider the output indicators. The trends in regional disparity with statistical significance at 10 percent level are summarized in Table 1.

Table 1: Trends in Regional Disparity in Output Indicators.

\begin{tabular}{|c|c|c|c|}
\hline Sector / Indicators & $\begin{array}{c}\text { During } \\
1980 \text { s }\end{array}$ & $\begin{array}{l}\text { During } \\
1990 s\end{array}$ & $\begin{array}{l}\text { Over two } \\
\text { decades }\end{array}$ \\
\hline (1) & $(2)$ & (3) & (4) \\
\hline 1. Poverty Percentage & Fall & Rise & Same \\
\hline $\begin{aligned} \text { 2. Percapita Cons. Expenditure }- & \text { Combined } \\
& - \text { Rural } \\
- & \text { Urban }\end{aligned}$ & $\begin{array}{l}\text { Fall } \\
\text { Same } \\
\text { Rise }\end{array}$ & $\begin{array}{l}\text { Same } \\
\text { Same } \\
\text { Fall }\end{array}$ & $\begin{array}{l}\text { Same } \\
\text { Same } \\
\text { Same }\end{array}$ \\
\hline $\begin{array}{r}\text { 3. Inflation - Inequality Adj. PCE - Rural } \\
\text { - Urban }\end{array}$ & $\begin{array}{l}\text { Same } \\
\text { Same }\end{array}$ & $\begin{array}{l}\text { Same } \\
\text { Fall }\end{array}$ & $\begin{array}{l}\text { Same } \\
\text { Same }\end{array}$ \\
\hline $\begin{array}{r}\text { 4. Gini Ratio of PCE - Rural } \\
\text { - Urban }\end{array}$ & $\begin{array}{l}\text { Fall } \\
\text { Fall }\end{array}$ & $\begin{array}{l}\text { Fall } \\
\text { Fall }\end{array}$ & $\begin{array}{l}\text { Fall } \\
\text { Fall }\end{array}$ \\
\hline $\begin{array}{r}\text { 5. HH with Safe Drinking Water - Combined } \\
\text { - Rural } \\
\text { - Urban }\end{array}$ & $\begin{array}{l}\text { Fall } \\
\text { Fall } \\
\text { Fall }\end{array}$ & $\begin{array}{l}\text { Fall } \\
\text { Fall } \\
\text { Fall }\end{array}$ & $\begin{array}{l}\text { Fall } \\
\text { Fall } \\
\text { Fall }\end{array}$ \\
\hline $\begin{array}{r}\text { 6. HH with Electricity Connect.- } \\
\text { - } \\
\text { - Rural } \\
\text { - Urban }\end{array}$ & $\begin{array}{l}\text { Fall } \\
\text { Fall } \\
\text { Fall }\end{array}$ & $\begin{array}{l}\text { Fall } \\
\text { Fall } \\
\text { Fall }\end{array}$ & $\begin{array}{l}\text { Fall } \\
\text { Fall } \\
\text { Fall }\end{array}$ \\
\hline $\begin{array}{ll}\text { 7. HH with Toilet Facility } & \text { - Combined } \\
& \text { - Rural } \\
& \text { - Urban }\end{array}$ & $\begin{array}{l}\text { Fall } \\
\text { Fall } \\
\text { Fall }\end{array}$ & $\begin{array}{l}\text { Fall } \\
\text { Fall } \\
\text { Fall }\end{array}$ & $\begin{array}{l}\text { Fall } \\
\text { Fall } \\
\text { Fall }\end{array}$ \\
\hline 8. Infant Mortality Rate & Fall & Same & Same \\
\hline 9. Mortality Rate for under 5 yrs. children & Same & NA & NA \\
\hline 10. Mortality Rate for 5-9 yrs. children & Same & NA & NA \\
\hline 11. Life Expectancy & Fall & Fall & Fall \\
\hline 12. Overall Sex Ratio & Fall & Same & Fall \\
\hline 13. Sex Ratio for age $0-4$ & Rise & Rise & Rise \\
\hline 14. Total Fertility Rate & Same & Fall & Same \\
\hline 15. Old age Dependency Ratio & Same & NA & NA \\
\hline 16. Child Labour (5-14 Years) & Same & NA & NA \\
\hline
\end{tabular}




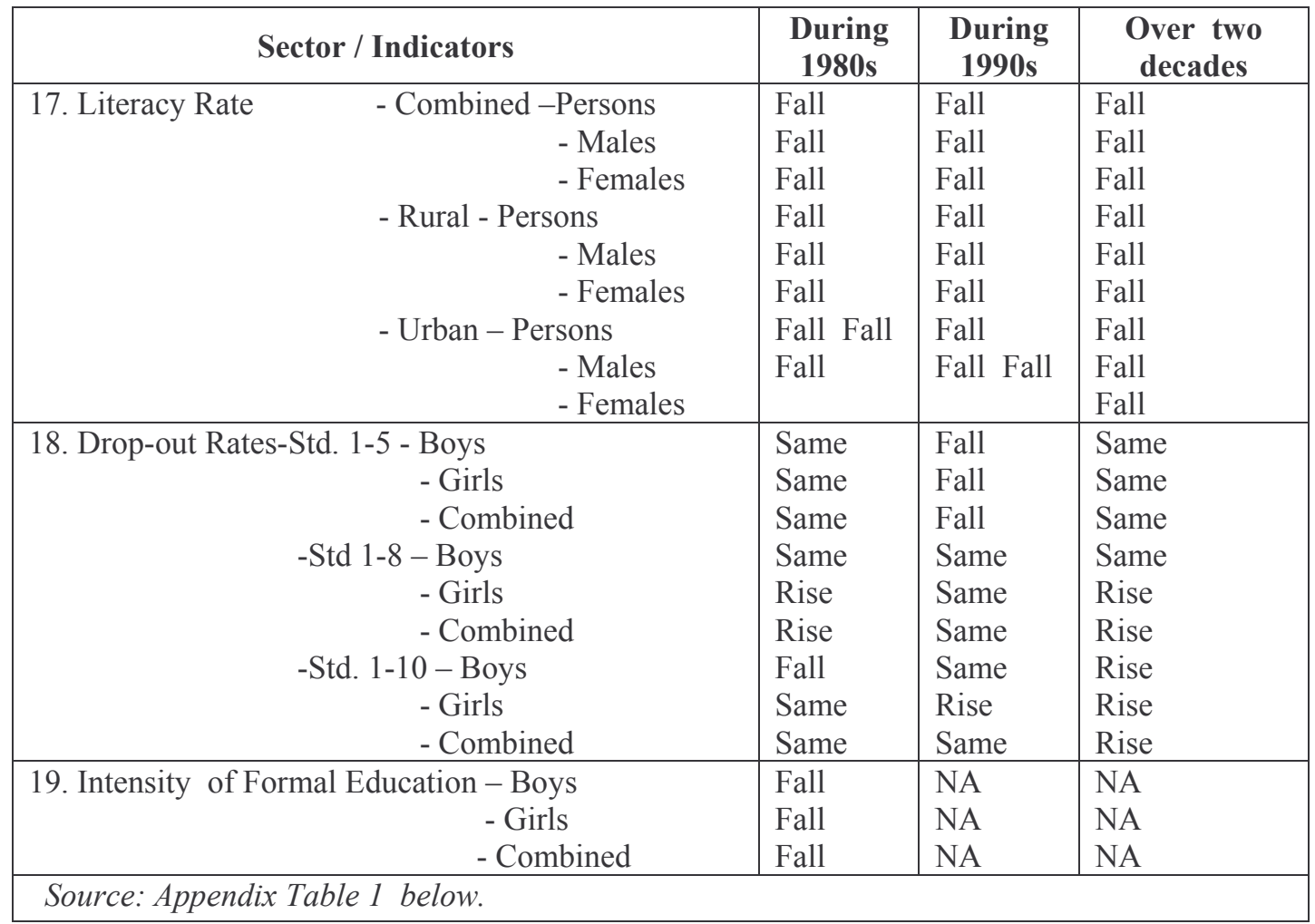

We have considered several output indices from the social sector reflecting overall wellbeing of population and their living conditions (Table 1). We have covered aspects like poverty, inequality, sanitation, mortality, life expectancy, sex ratio, fertility, literacy, education, oldage dependency and child labour. We find that most of the indicators have shown a statistically significant decline in the regional disparity over the last two decades. There are only a couple of indicators like sex ratio for the ages $0-4$, and drop out rates for standards 1 to 10 among boys and girls, where the regional disparity has increased over the last two decades. Thus, the impression that several development indicators other than SDP also show a marked increase in regional disparity over the last two decades does not find any strong empirical support. The impression is perhaps based on the behaviour of disparity in poverty proportion during the 1990s. Those estimates, in any case, are seriously challenged for comparability over time and space on account of different concepts and methods used in measurement (see, Tendulkar and Sundaram, 2001; Deaton and Dreze, 2002; and Sen, 2004). What is more puzzling is that, while researchers are unanimous in challenging the official estimates, there is no consensus on the adjustments required to make the estimates comparable over time. Moreover, when we consider related aspects like consumption expenditure and inequality over the same time duration, regional disparity has either remained the same or fallen. Thus, poverty proportion could be very unreliable and misleading indicator to conclude on the trend in regional disparity in India.

Table 1 brings out the major areas of concern where regional disparity is either rising or remaining the same over time. These are poverty and consumer expenditures, mortality among children and infants, sex ratio among children and infants, fertility rates, child labour, and school drop out rates. Planning for social sectors in the country needs to focus on the laggard states in these areas. In all other areas like sanitation, overall literacy, life expectancy, drinking water, consumer expenditure inequality, etc., regional disparity is on decline.

We may now turn to the input indicators. Table 2 presents the corresponding statistically significant trends found in regional disparity over the 1980s and the 1990s. 
Major problem with the input indicators seems to be the availability of comparable data over last two decades. Several indicators have been available only from early nineties in response to the requirements of some multilateral agencies. It is indicative of the approach and methodology of economic planning followed in the country till 1990. It was all along financial planning and monitoring of the financial targets rather than considering any physical planning with monitoring physical targets. All along it was implicitly assumed that financial allocation and approval of government expenditures would result in physical facilities, inputs and supply of services.

Table 2: Trends in Regional Disparity in Input Indicators.

\begin{tabular}{|c|c|c|c|}
\hline Sector / Indicators & $\begin{array}{l}\text { During } \\
1980 \mathrm{~s}\end{array}$ & $\begin{array}{l}\text { During } \\
1990 s\end{array}$ & $\begin{array}{l}\text { Over two } \\
\text { decades }\end{array}$ \\
\hline$(1)$ & $(2)$ & (3) & $(4)$ \\
\hline 1. \% of Consumption Expen. On Food - Rural & Fall & Same & Same \\
\hline 2. \% of Consumption Expn. Of non-Food- Rural & Fall & Same & Fall \\
\hline 3. Percapita Consumption of Electricity & Same & Same & Same \\
\hline $\begin{array}{r}\text { 4. Labourforce Participation Rate - Persons } \\
\text { - Males } \\
\text { - Female }\end{array}$ & $\begin{array}{l}\text { Same } \\
\text { Fall } \\
\text { Fall }\end{array}$ & $\begin{array}{l}\text { Fall } \\
\text { Fall } \\
\text { Fall }\end{array}$ & $\begin{array}{l}\text { Fall } \\
\text { Fall } \\
\text { Fall }\end{array}$ \\
\hline $\begin{array}{l}\text { 5. Road connect - \% of Villages (Pop. }<1000) \\
\qquad \text { (Pop. 1000-1500) } \\
\text { (Pop. }>1500)\end{array}$ & $\begin{array}{l}\text { NA } \\
\text { NA } \\
\text { NA }\end{array}$ & $\begin{array}{l}\text { Fall } \\
\text { Fall } \\
\text { Same }\end{array}$ & $\begin{array}{l}\text { NA } \\
\text { NA } \\
\text { NA }\end{array}$ \\
\hline $\begin{aligned} \text { 6. Enrolment Ratio - 6-11 years }- & \text { Children } \\
& - \text { Boys } \\
& - \text { Girls } \\
& -11-14 \text { years }- \text { Children } \\
& - \text { Boys } \\
& - \text { Girls }\end{aligned}$ & $\begin{array}{l}\text { Fall } \\
\text { Same } \\
\text { Fall } \\
\text { Fall } \\
\text { Fall } \\
\text { Fall }\end{array}$ & $\begin{array}{l}\text { NA } \\
\text { NA } \\
\text { NA } \\
\text { NA } \\
\text { NA } \\
\text { NA }\end{array}$ & $\begin{array}{l}\text { NA } \\
\text { NA } \\
\text { NA } \\
\text { NA } \\
\text { NA } \\
\text { NA }\end{array}$ \\
\hline $\begin{aligned} & \text { 7. Pupils per Teacher - } \text { Primary } \\
& \text { - Upper Primary } \\
& \text { - Secondary }\end{aligned}$ & $\begin{array}{l}\text { Same } \\
\text { Same } \\
\text { Same }\end{array}$ & $\begin{array}{l}\text { Fall } \\
\text { Same } \\
\text { Fall }\end{array}$ & $\begin{array}{l}\text { Fall } \\
\text { Same } \\
\text { Same }\end{array}$ \\
\hline $\begin{aligned} \text { 8. Schools per } 1000 \text { population } & \text { - Primary } \\
& \text { - Upper Primary }\end{aligned}$ & $\begin{array}{l}\text { Fall } \\
\text { Fall }\end{array}$ & $\begin{array}{l}\text { Fall } \\
\text { Same }\end{array}$ & $\begin{array}{l}\text { Fall } \\
\text { Same }\end{array}$ \\
\hline $\begin{array}{l}\text { 9. \% Births Attended by Health Professionals } \\
\text { - Delivered in Medical Instt. }\end{array}$ & $\begin{array}{l}\text { NA } \\
\text { NA }\end{array}$ & $\begin{array}{l}\text { Fall } \\
\text { Fall }\end{array}$ & $\begin{array}{l}\text { NA } \\
\text { NA }\end{array}$ \\
\hline 10. $\%$ of $>2$ dose of TT Vacci. during Pregnancy & NA & Fall & NA \\
\hline $\begin{array}{l}\text { 11. \% Fully Vaccinated Children aged } 12-23 \\
\text { Months. }\end{array}$ & NA & Fall & NA \\
\hline 12. Couple Protection Rate & NA & Fall & NA \\
\hline
\end{tabular}

Whatever readily available evidences we have on the input indicators (certainly incomplete and not exhaustive) we find from Table 2 that none of the indicators during the 1980s and the 1990s and over the two decades show increase in regional disparity. In fact, most of them show a statistically significant decline in regional disparity over recent years. Thus, during the last two decades, there has been a conscious and substantial effort to create enabling circumstances and provide inputs to reduce regional disparity in several different aspects of developmental inputs like roads in rural areas, education, health, birth control, consumption of electricity, food and non-food consumption expenditures, and labour force participation. These are all the social and economic sectors covered in the planning exercise not only at the central level but also at the state level. Regional disparity in these indicators showing either constancy or a decline over time does signify some resolve of policy makers and seriousness of implementation of the plans. 


\section{STATE GOVERNMENTS' EFFORTS}

Social sectors, particularly education and health, are the subjects under state governments' purview to a large extent. Though the central government has also definite role to play through special schemes and programmes directly conducted. State governments' efforts are often measured through their expenditures over time. Since the distinction between the revenue expenditures and capital expenditures is more in terms of administrative powers and controls rather than in terms of the nature of expenditures - consumption or investment, it is important to consider both these categories of expenditures for such social sectors to measure the efforts of the government. In order to estimate total quantum of the effort put in by different state governments in these sectors, we may ignore depreciation and add linearly the efforts over the decade. Obviously, we have to consider the expenditures at constant prices and on a per capita basis to make the estimates meaningful. Similar measure of government effort was also used by Archana Dholakia ( 1990 ). She had used the SDP deflators to convert the government expenditures into corresponding constant prices. We have also followed the same method and taken 1993-94 as the base year for constant prices. These estimates by three sub-sectors - education, health and other social sectors - by revenue and capital expenditures for the decades of the 1980s and 1990s are presented in Table 3 And Table 4 respectively.

We can see that states have made considerably high per capita aggregate effort in real terms during the decade of the 1990s over the decade of the 1980s in other social sectors than education and health. In education also the effort is substantially higher during the 1990s over the 1980s. However, the effort is almost the same in the health sector on per capita basis. There are substantial variations in the effort in different sectors during the two decades across states. Tables 3 and 4 together reflect priorities and emphasis of different states among the social sectors and changes therein over the two decades. These efforts by state governments are largely based on the felt need and perceived gaps in the development of their states. They may not be consciously and strategically decided policies to reduce the regional imbalance or interstate disparities. Still, however, we find that the input indicators in all these sub-sectors like education, health, sanitation etc., show a significant reduction in regional disparity during the 1990s. This is somewhat surprising particularly in the health sub-sector because the per capita real expenditure effort has not changed significantly during the 1990s over the 1980s. Even in terms of output indicators, the interstate disparity has declined by and large in all subsectors.

There are three possible reasons for this: (1) private sector also spends on such services' and over time, those efforts might have increased; (2) the central government expenditures in real terms might have increased in the laggard states correcting the imbalance and (3) there might be a very high positive correlation among per capita real expenditures in different social subsectors, and the output and input indicators might be affected positively by a combination of the social expenditures rather than only by the respective sub-sector's expenditure. It is seen from the correlation matrices among per capita real expenditures on social sub-sectors reported in Table 5 that the last reason is valid in India not only over the 1980s but also over the 1990s. All the correlations among the revenue and capital real expenditures in education, health and other social sub-sectors are positive and highly significant during both the decades. Thus, the states on an overage spend more or less in all social sub-sectors rather than selectively choosing one or two sub-sectors. 


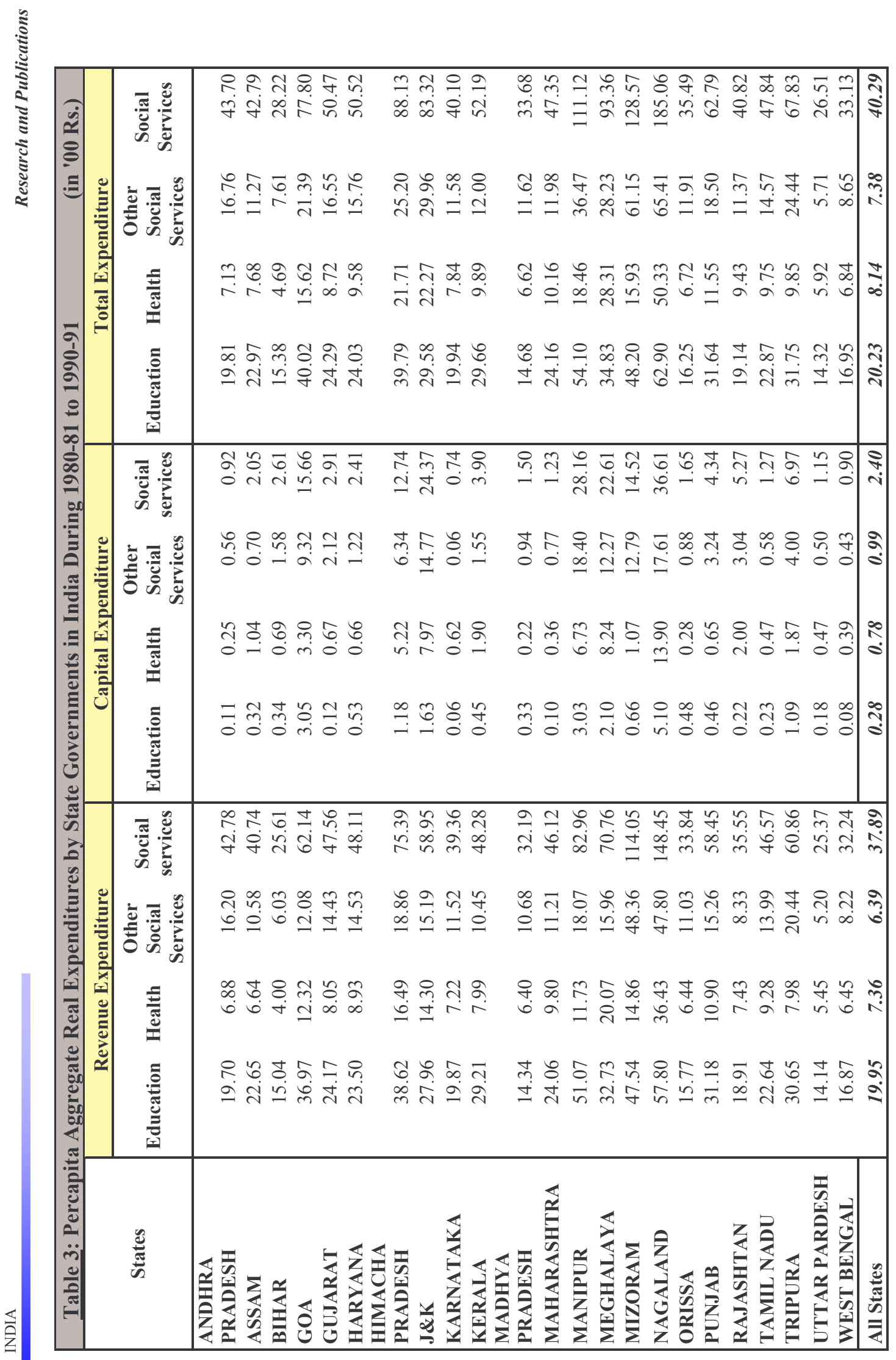




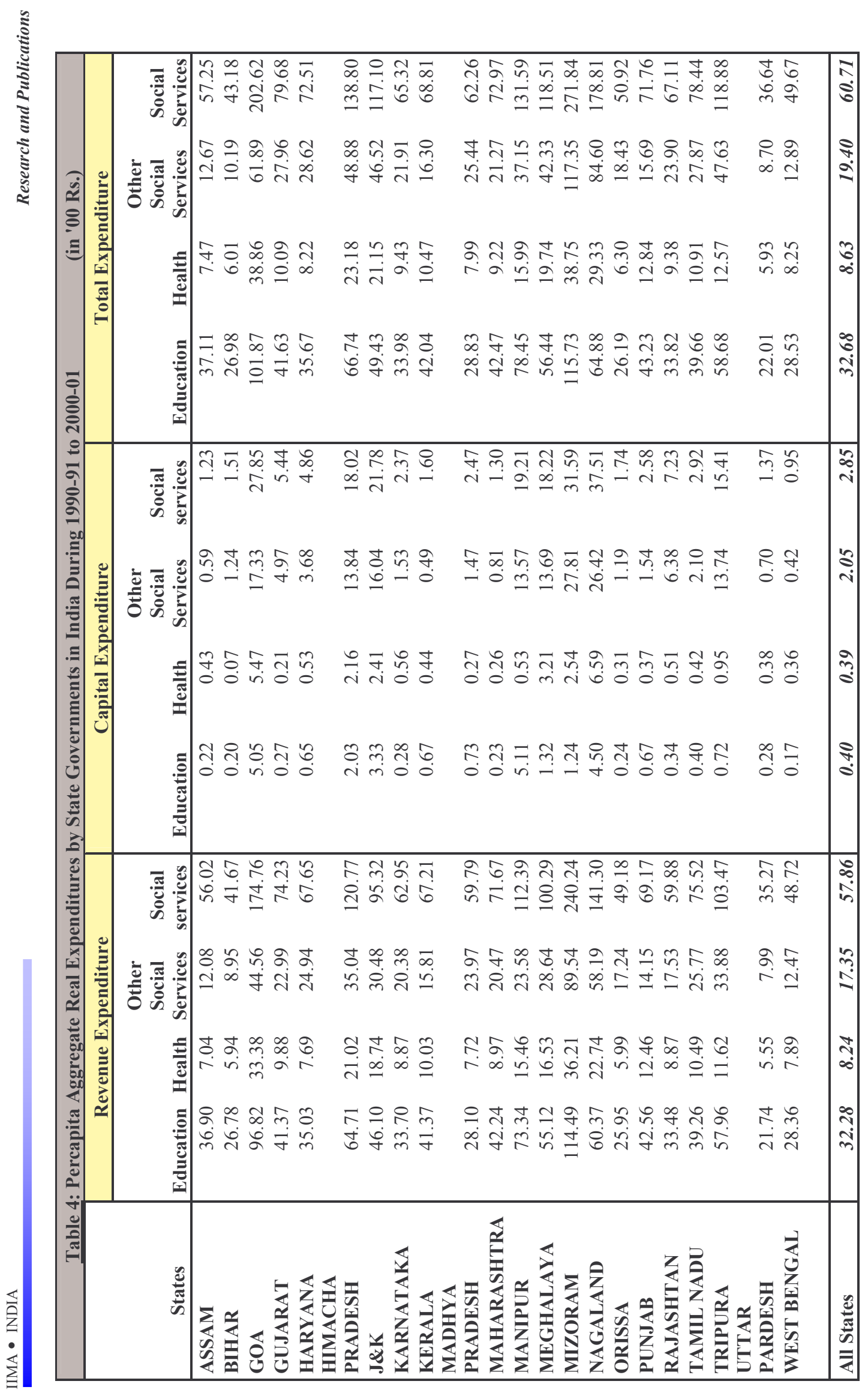




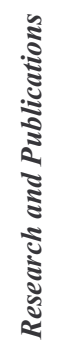

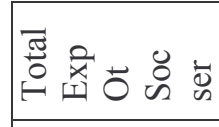

高最高

离|
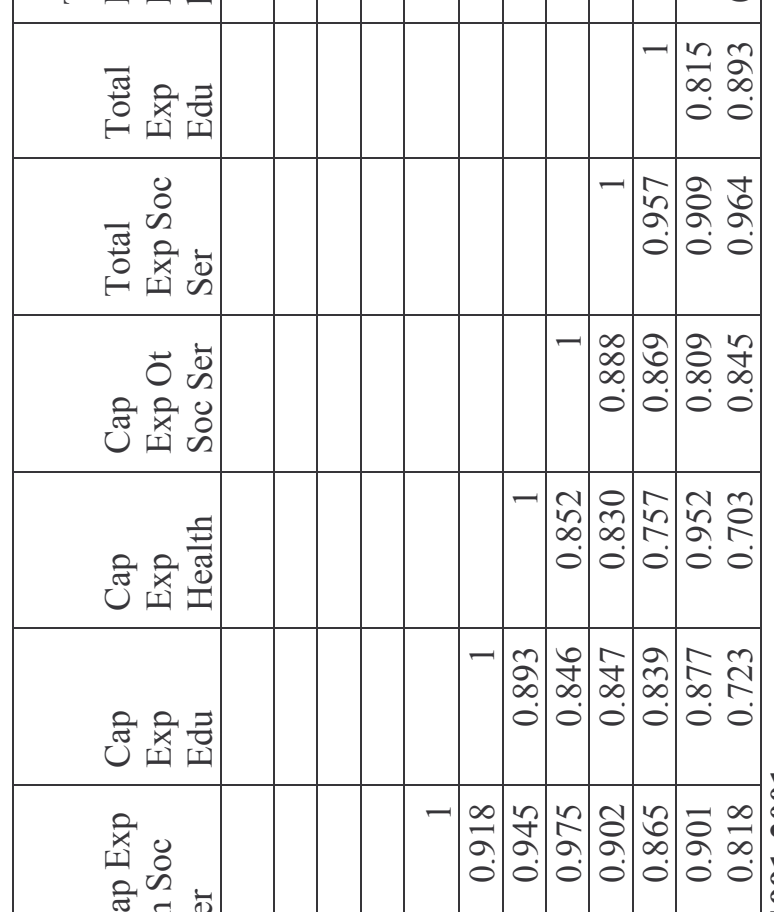

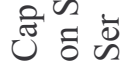

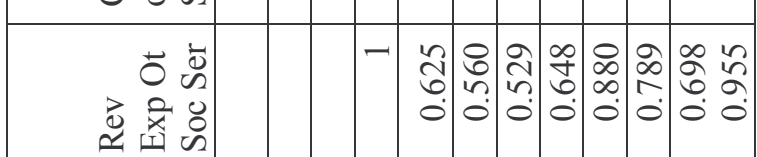

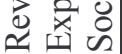

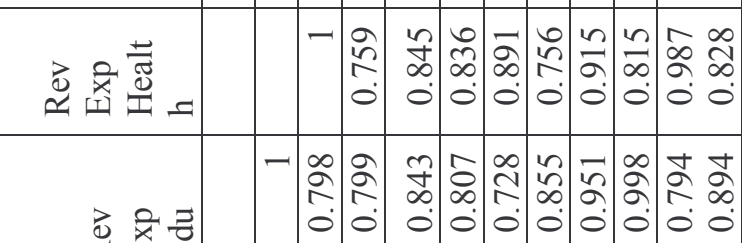

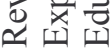

б

> मे

$\simeq$ 的

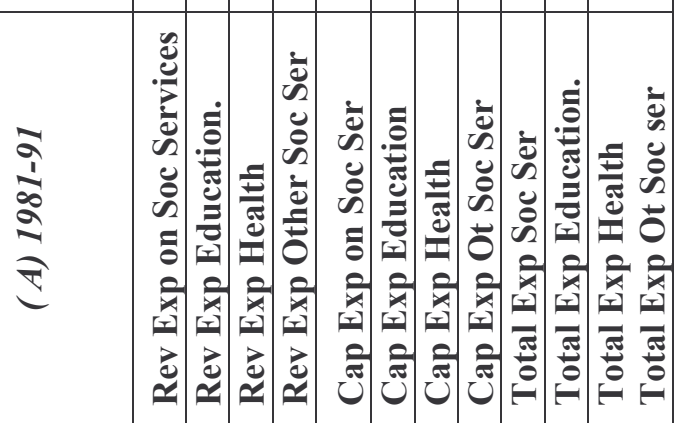

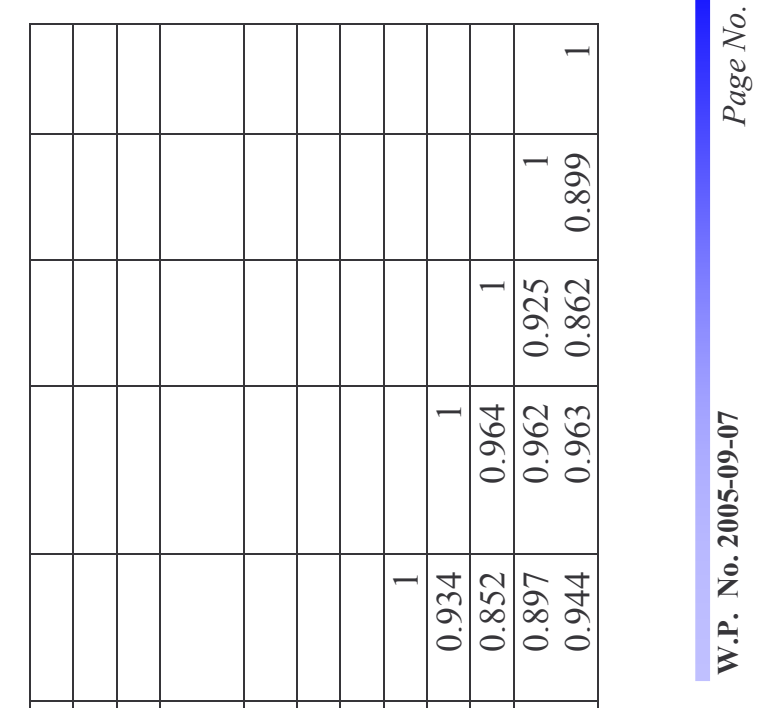

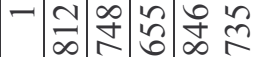

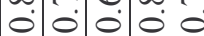

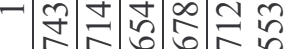

$\dot{0} \dot{0} \dot{0} 0 \dot{0} 00$

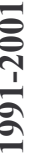

ص

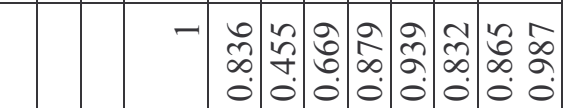

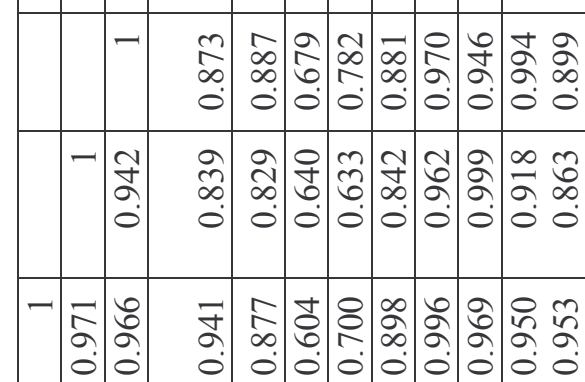

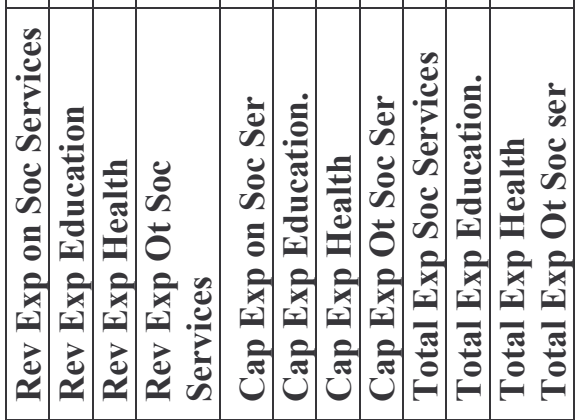


Finally, we consider the question of the trend of regional disparity in the state governments' efforts in the social sectors. We follow the same methodology as outlined in Section 2 above for the per capita real state government expenditures on social sectors over a decade. Table 6 presents the results.

It can be seen from Table 6 that regional disparity in real revenue expenditure on education and total social sectors, and total real expenditures on education and all social sectors together has remained the same during the 1990s compared to the 1980s. But, all other subsectors like health and other social sectors, and real capital expenditures on all social sub-sectors show a clear decline in the regional disparity during 1990s compared to the 1980s. Since regional disparity in state governments' efforts in all social sub-sectors except education is declining, we find interstate disparity falling in most of the input and output indicators over the period. It is not a coincidence, therefore, that the regional disparity in selective educational output and input indicators show a constancy or an increase over the last two decades, because the interstate disparity in state governments efforts in educational sub-sector has not been reducing over the last two decades. Somehow, the laggard states have not felt the need and political pressure to increase their efforts in this direction.

Table 6: Trend in Interstate Disparity in Government Real Expenditures during 1990s over 1980s in India.

\begin{tabular}{|l|r|r|l|l|l|r|r|}
\hline Varialbles & \multicolumn{1}{|l|}{$\begin{array}{l}\text { Interce- } \\
\text { pt 'a' }\end{array}$} & Slope'b' & $\begin{array}{l}\text { t-Stat } \\
\text { for } \\
\mathbf{a}=\mathbf{0}\end{array}$ & $\begin{array}{l}\text { t-Stat } \\
\mathbf{b}=\mathbf{1}\end{array}$ & $\begin{array}{l}\text { R } \\
\text { Square }\end{array}$ & $\begin{array}{l}\text { F-Value } \\
\text { States } \\
\text { \& UTs }\end{array}$ \\
\hline Rev Exp Edu & 0.11 & 0.96 & 0.484 & -0.256 & 0.648 & 38.66 & 23 \\
\hline Rev Exp Health & 0.63 & 0.66 & 1.933 & -1.797 & 0.358 & 11.70 & 23 \\
\hline Rev Exp Ot Soc Ser & 0.19 & 0.54 & 1.076 & -7.842 & 0.806 & 87.31 & 23 \\
\hline Rev Exp Tot Soc ser & 0.24 & 0.86 & 1.008 & -1.003 & 0.630 & 35.80 & 23 \\
\hline Cap Exp Education & 0.39 & 0.80 & 0.833 & -2.376 & 0.808 & 88.34 & 23 \\
\hline Cap Exp Health & 0.73 & 0.75 & 0.968 & -1.822 & 0.593 & 30.55 & 23 \\
\hline Cap Exp Ot Soc Ser & 0.63 & 0.60 & 1.099 & -5.435 & 0.755 & 64.77 & 23 \\
\hline Cap Exp Tot Soc ser & 0.63 & 0.81 & 1.219 & -2.044 & 0.777 & 73.00 & 23 \\
\hline Total Exp Education & 0.14 & 0.93 & 0.638 & -0.454 & 0.658 & 40.48 & 23 \\
\hline Total Exp Health & 0.71 & 0.58 & 2.274 & -2.707 & 0.406 & 14.35 & 23 \\
\hline $\begin{array}{l}\text { Total Exp Other Soc } \\
\text { services }\end{array}$ & 0.13 & 0.58 & 0.658 & -7.447 & 0.831 & 103.00 & 23 \\
\hline Total Exp Soc Ser & 0.27 & 0.83 & 1.174 & -1.369 & 0.666 & 41.89 & 23 \\
\hline
\end{tabular}

Source: Tables 3 and 4

\section{SUMMARY AND POLICY IMPLICATIONS}

In the present paper, we have examined trends in regional disparity in human and social development by considering numerous indicators other than SDP. We found no support to the general impression prevailing in the recent literature that disparity is increasing over the last two decades when we subjected the trend to statistical significance test. We considered the output as well as the input indicators for the purpose. In very few indicators, the disparity showed an increase, whereas in a large number of indicators it either remained the same or actually declined. The state governments' efforts in the social sectors were perhaps a major reason for the outcome. Except education, in all other social sub-sectors, the interstate disparity in the government effort markedly declined during the 1990s compared to the 1980s. In education, it remained the same. 
Our findings here point to a very clear policy prescription. The social and human development is considered by all the state governments as very important and a priority sector in their development strategy. The way they are making efforts in these directions is disparity reducing although each state has been acting on its own. This is perhaps because of the felt need of people and the polity in states. Explicit objective of reducing regional disparity in social and human development in the central planning may not, therefore, be specially required. Augmenting the revenue resources of states allowing the states to access public borrowings directly would enable most of them to concentrate on their priority areas - based on the local felt need. It is likely to address the issue of regional imbalance and disparity in a much better and efficient way without imposing excess burden since it would allow exploiting complementarity in growth and equity.

[Acknowledgement: I would like to thank Shri Shreekant Iyengar for providing useful assistance in computations and to Dr. Archana Dholakia for making available details of state expenditures for the years 1981-91.]

\section{REFERENCES}

1. Deaton A. and Dreze J. ( 2002): "Poverty and inequality in India - A Re-examination", Economic and political Weekly, Sept. 7.

2. Dholakia Archana (1990): Benefits from Government Expenditure in India-A Welfare Indicator Approach, Mumbai: Himalaya Publications.

3. Dholakia R.H. (1994): "Spatial Dimension of Acceleration of Economic Growth in India", Economic and Political Weekly, Vol. 29, No. 35, Aug. 21.

4. Dholakia R.H. (2003): "Regional Disparity in Economic and Human Development in India", Economic and Political Weekly, Vol. 38, No. 39, Sept. 27.

5. EPW Research Foundation (2003): Domestic Product of States of India, 1960-61 to 2001-01, Mumbai : June.

6. Misra B.S. ( 2005): “ Are Indian States Converging in the Post-Reform Period?: An Empirical Inquiry", Journal of Quantitative Economics, New Series Vol. 3, No. 1, January.

7. Morris M.D. ( 1979): Measuring Conditions of the World's Poor: Physical Quality of life Index, Washington D.C: Overseas Development Council.

8. Planning Commission (2002): National Human Development Report 2001, New Delhi, March.

9. Sen Abhijit and Himanshu (2004): "Poverty and Inequality in India-I and II", Economic and Political Weekly, Vol. 39, Nos. 38 and 39, Sept. 18 and 25.

10. Sundaram K. and Tendulkar S.D. (2001): "NAS-NSS Estimates of Private Consumption for Poverty Estimation - A Disaggregated Comparison for 1993-94", Economic and Political Weekly, Jan. 13. 


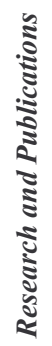

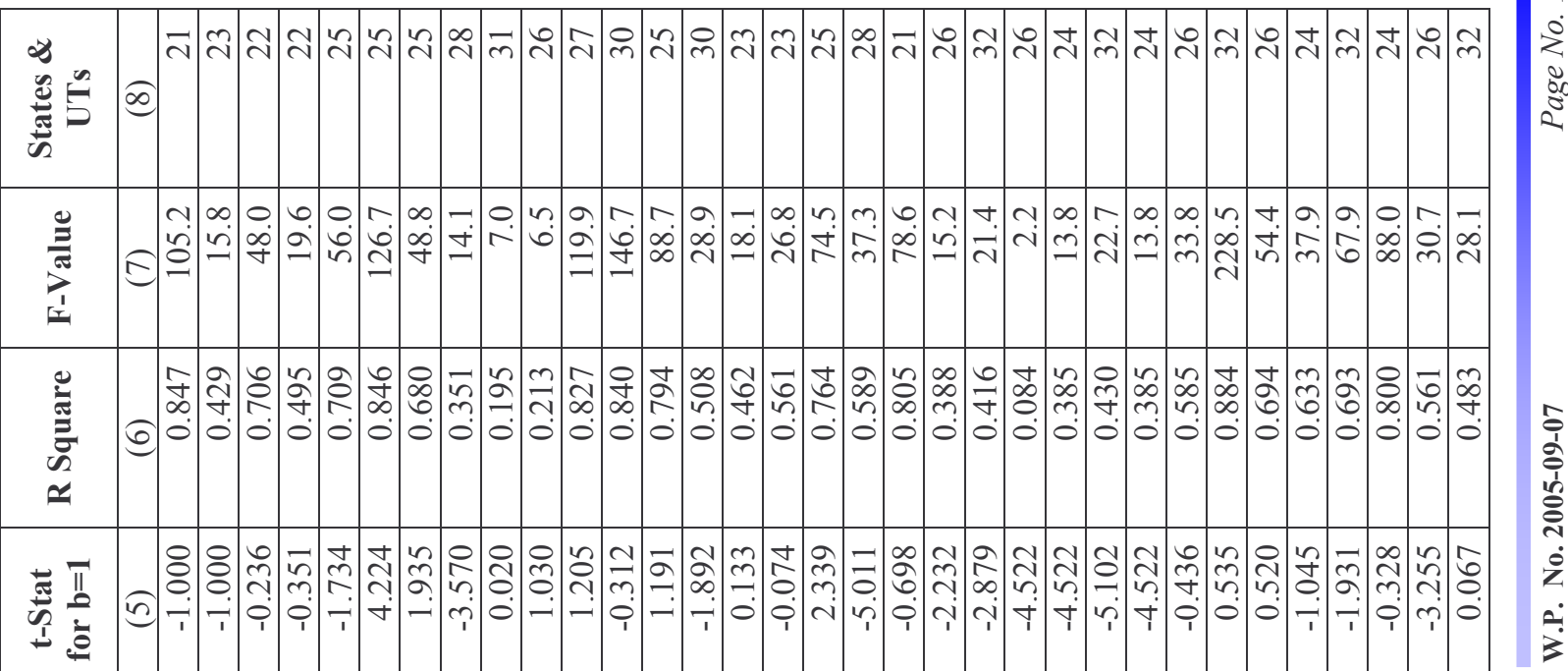

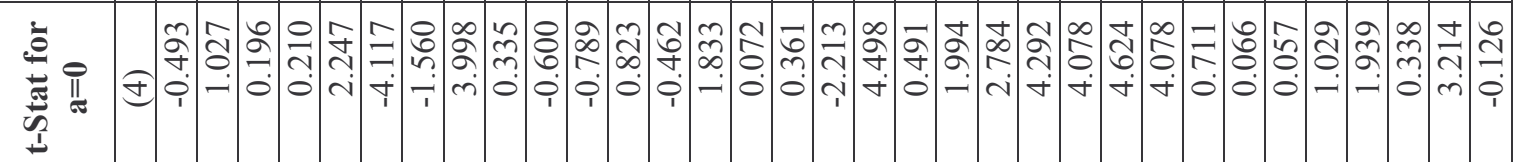

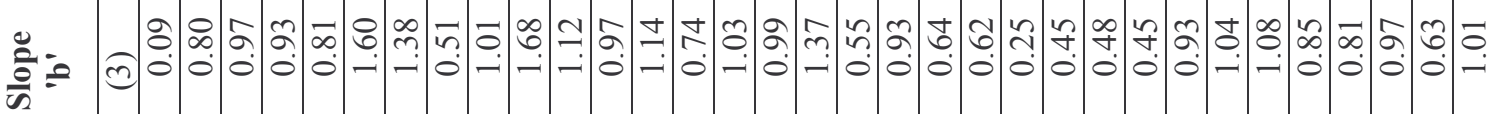

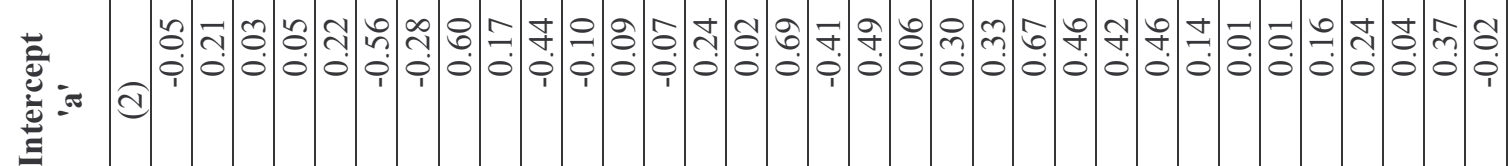

.

:

实

ฮี

$\cdot \frac{0}{30}$

.

을

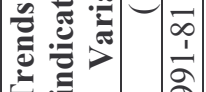

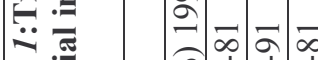

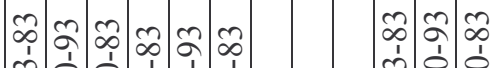

๙ิ

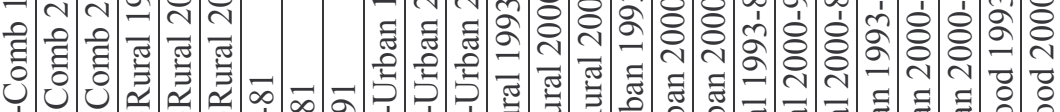

ふ2.

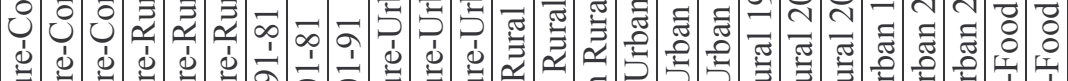

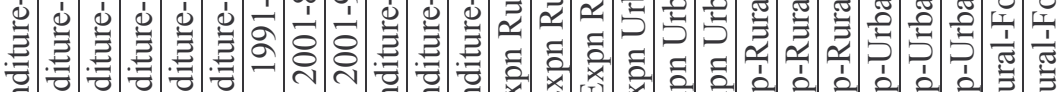

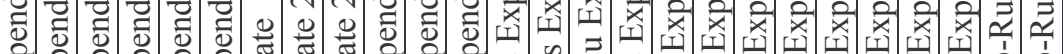
ڤँ ङ

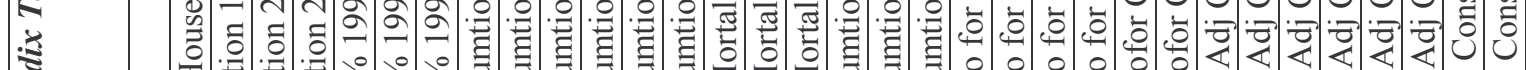

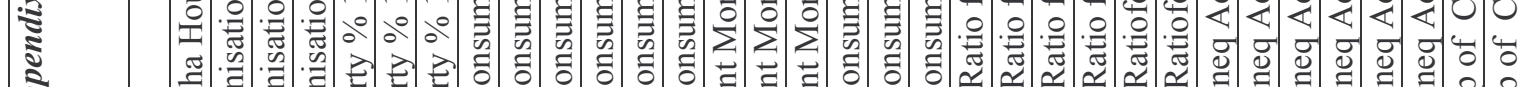
₹ $\quad$ 仓

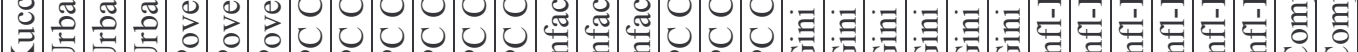
壬

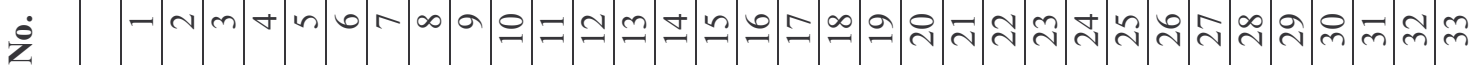




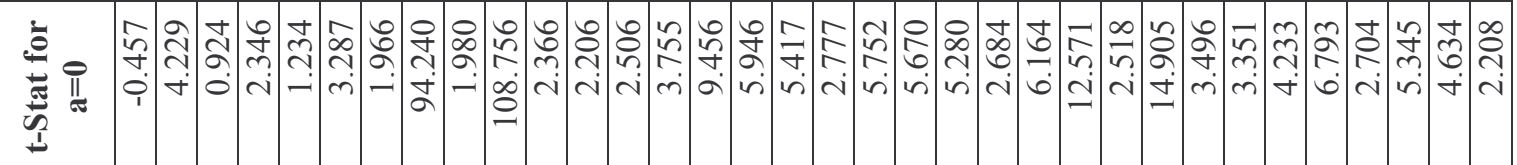

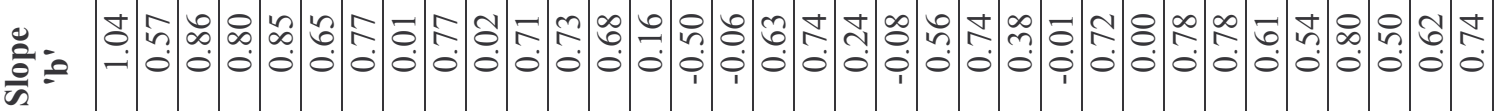

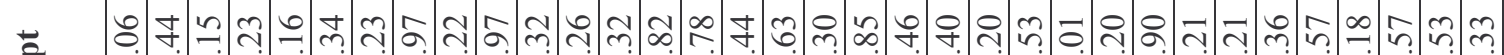
苞.

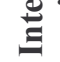

ב

-

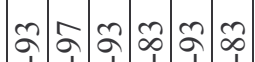

כ)

1่

๗

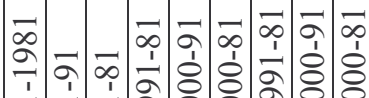

ᄀا

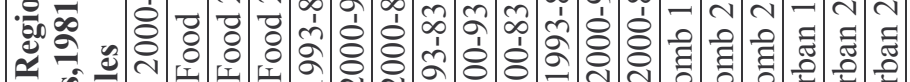

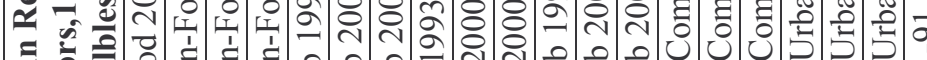

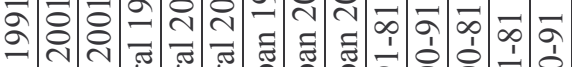
○。ㅇำ

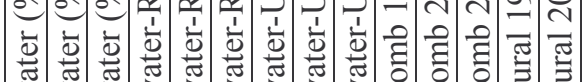

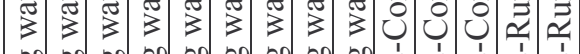
:

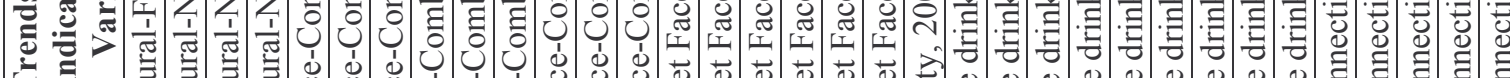

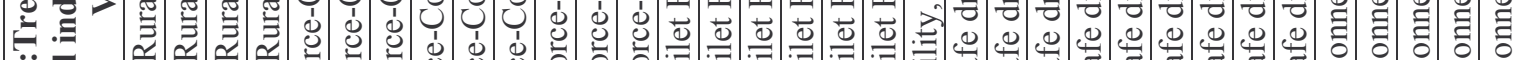

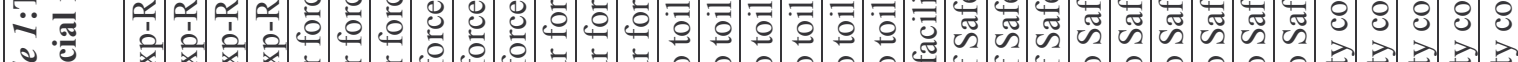

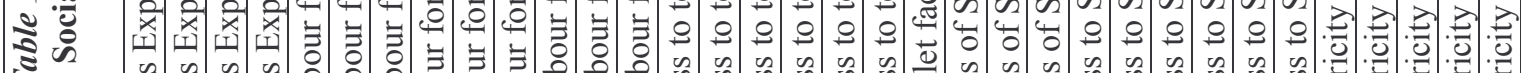

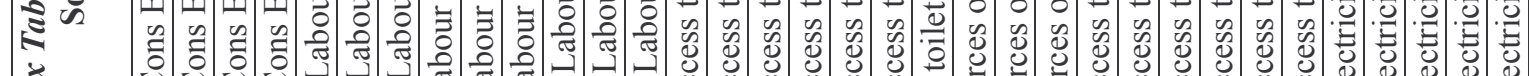

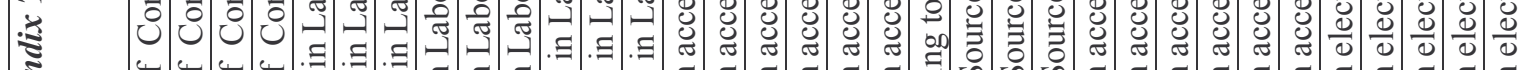

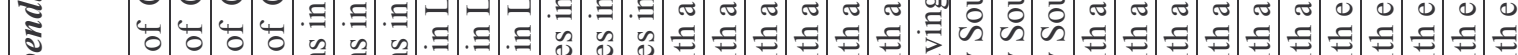

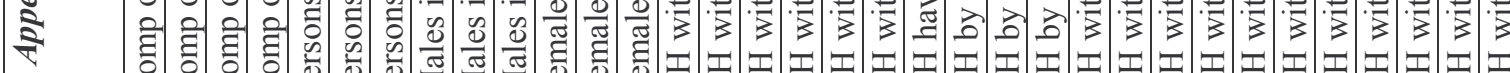
ठ⿹𠃌

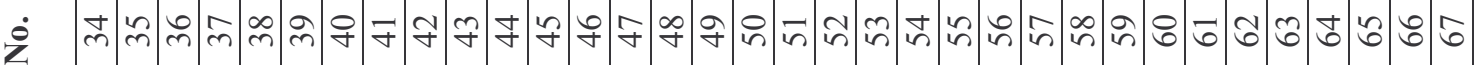
$\dot{\omega}$ 


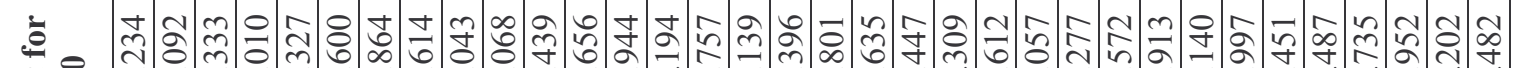

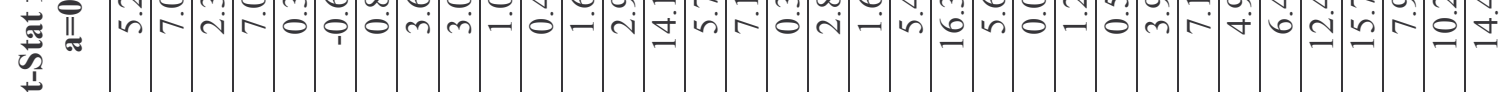

严=

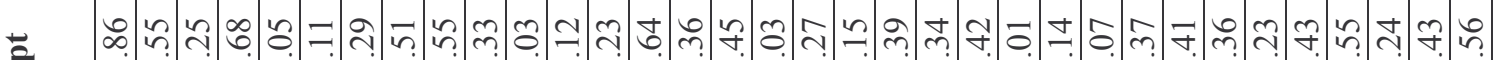

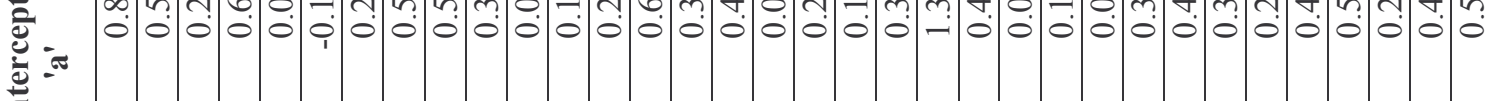
㧝

政

$\bar{a}$

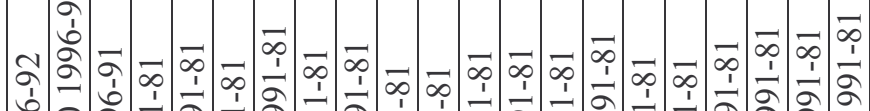
よ่。

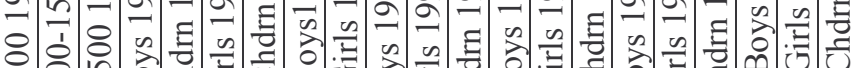

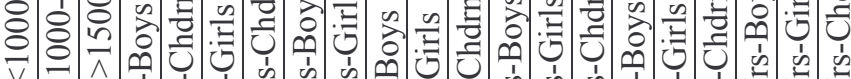

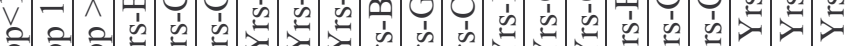

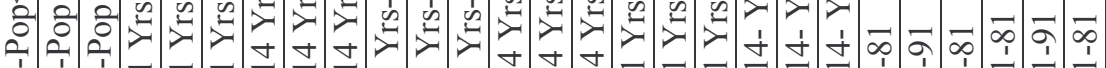

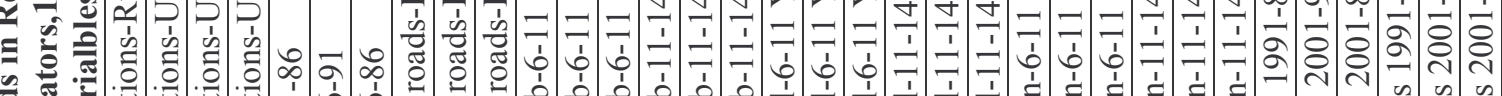
ฯ

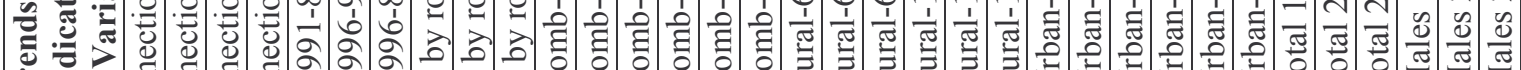
๘

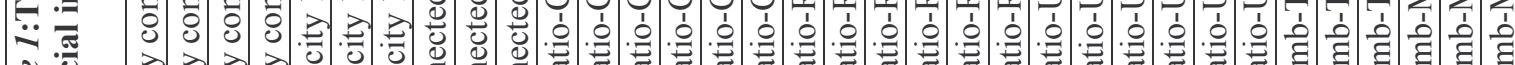

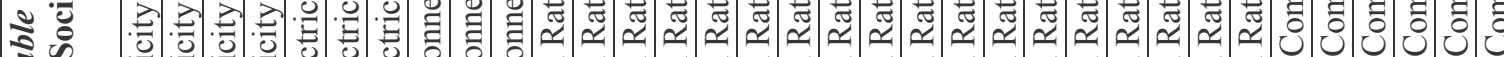
ङ

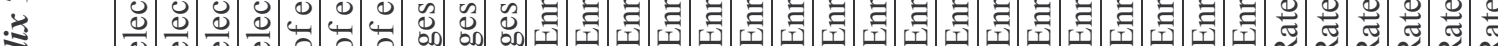

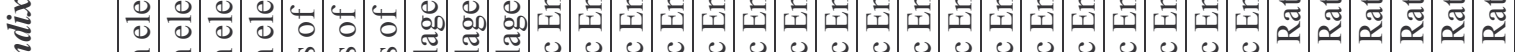

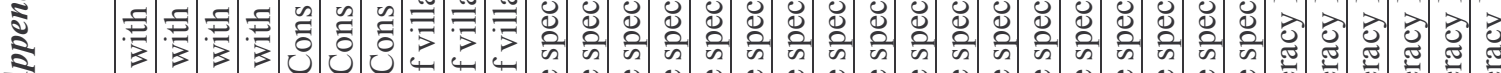

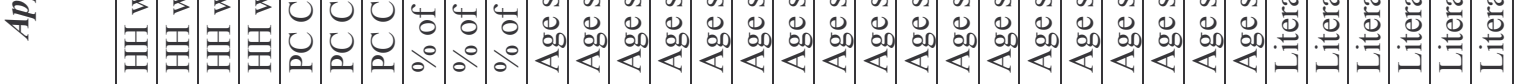

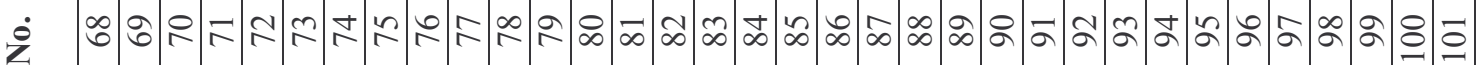
$\dot{\vec{S}}$ 
ڤ.

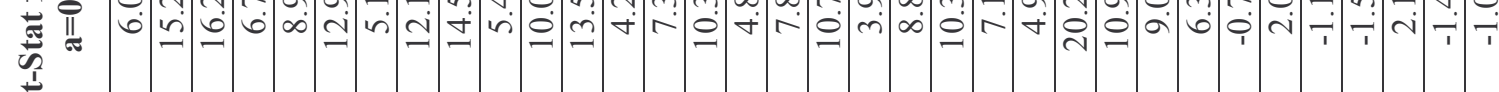

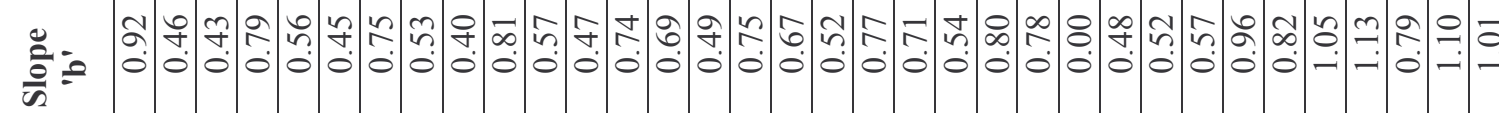

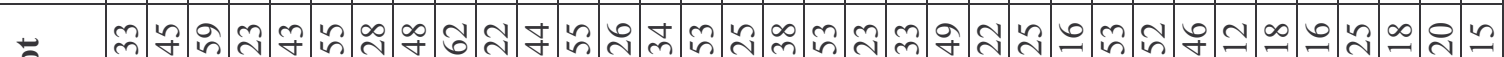

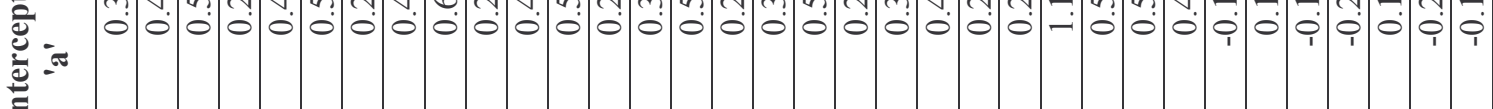
$\stackrel{\Xi}{\Xi}$

ב

ํㅡㄹ

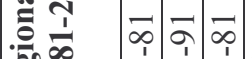

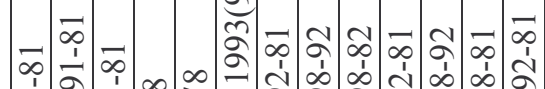

華:

¿ シ

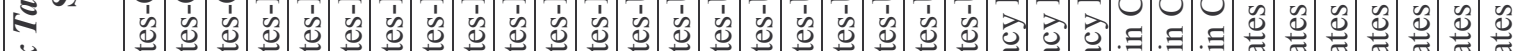

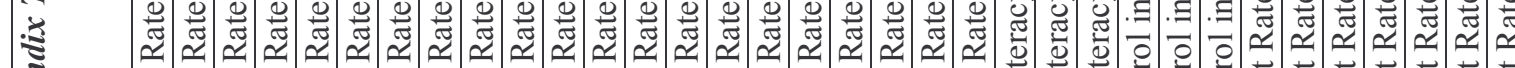

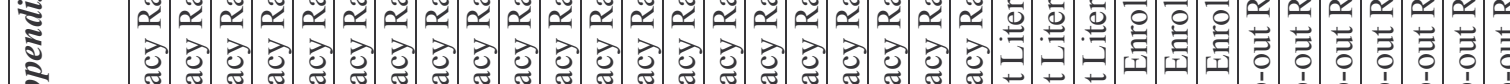

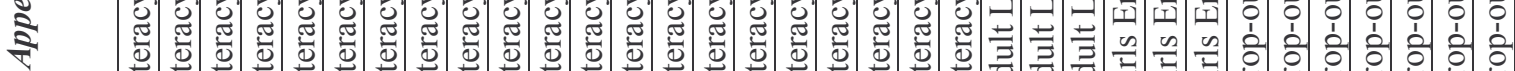
:

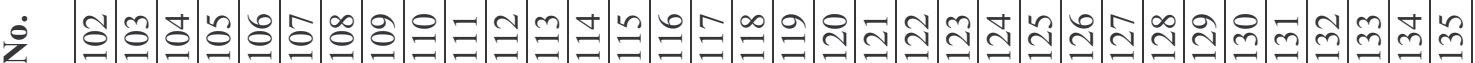
$\dot{\omega}$ 


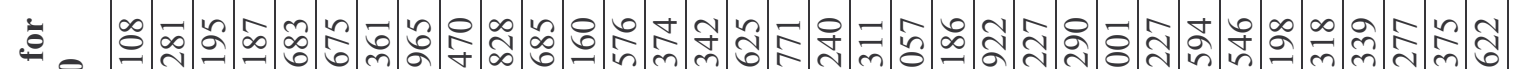
焉少

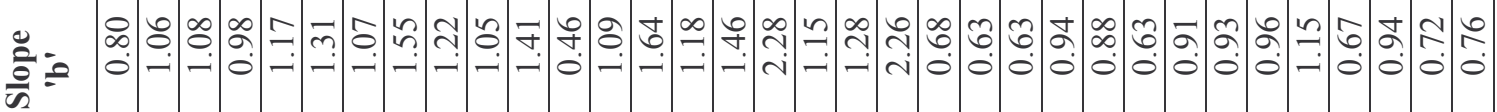

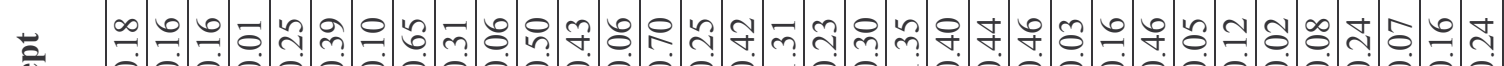

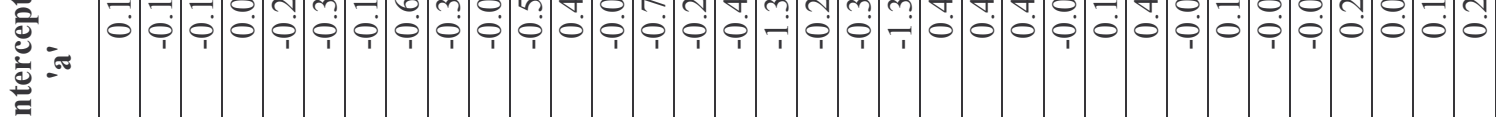
$\stackrel{\Xi}{\Xi}$

:

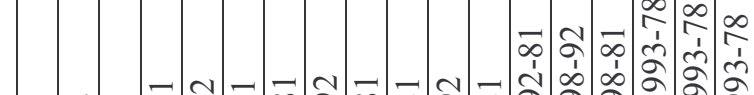

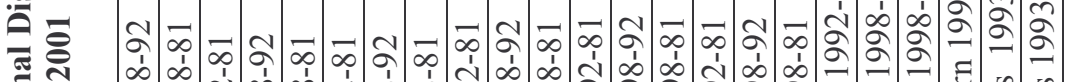

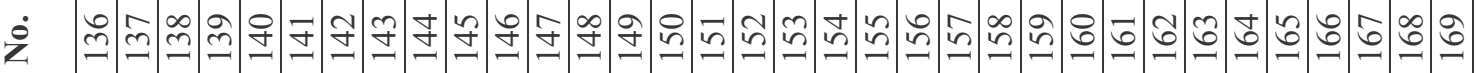


בัँ

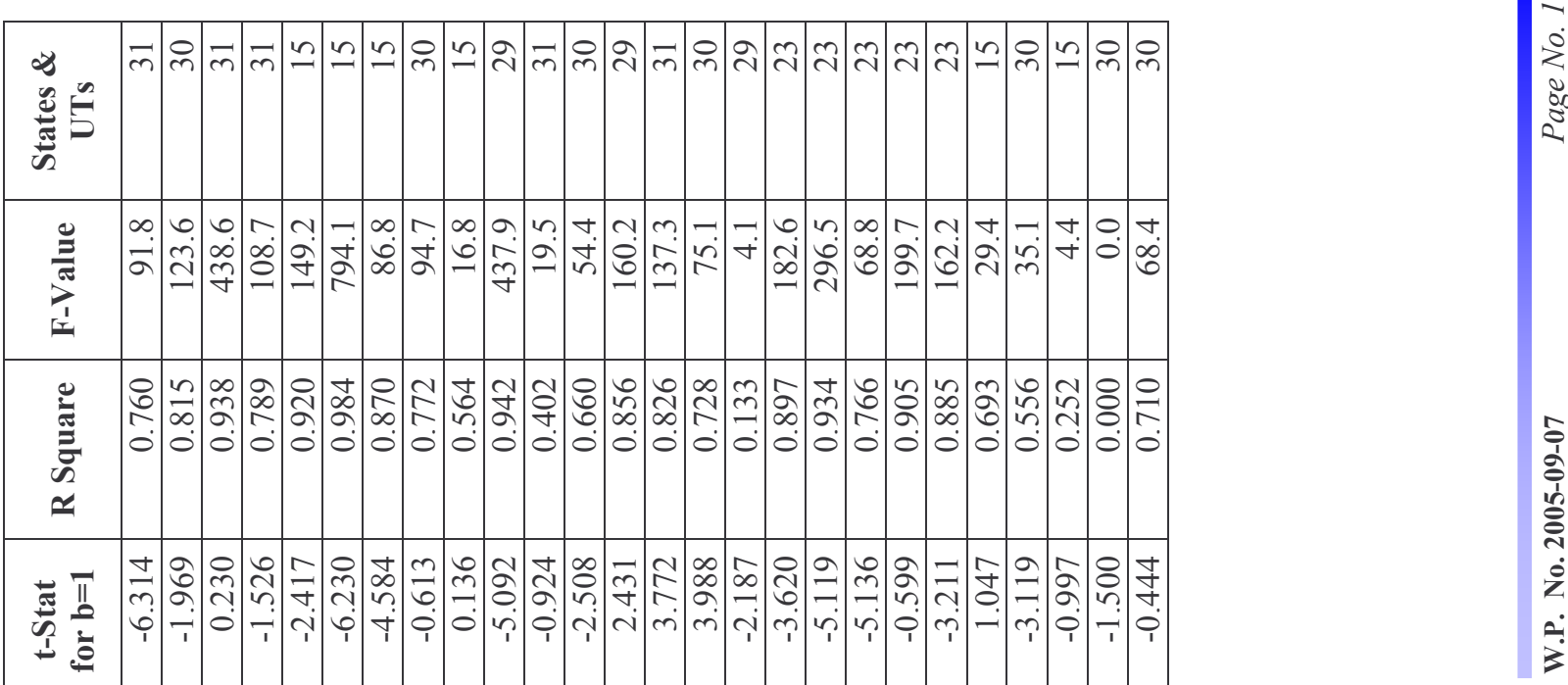

؛ै

窇

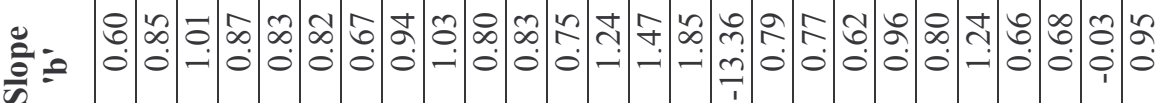

艹

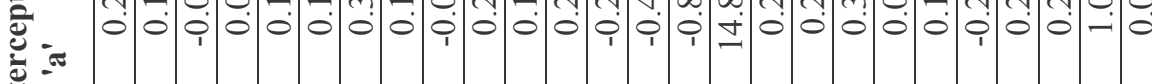

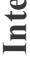

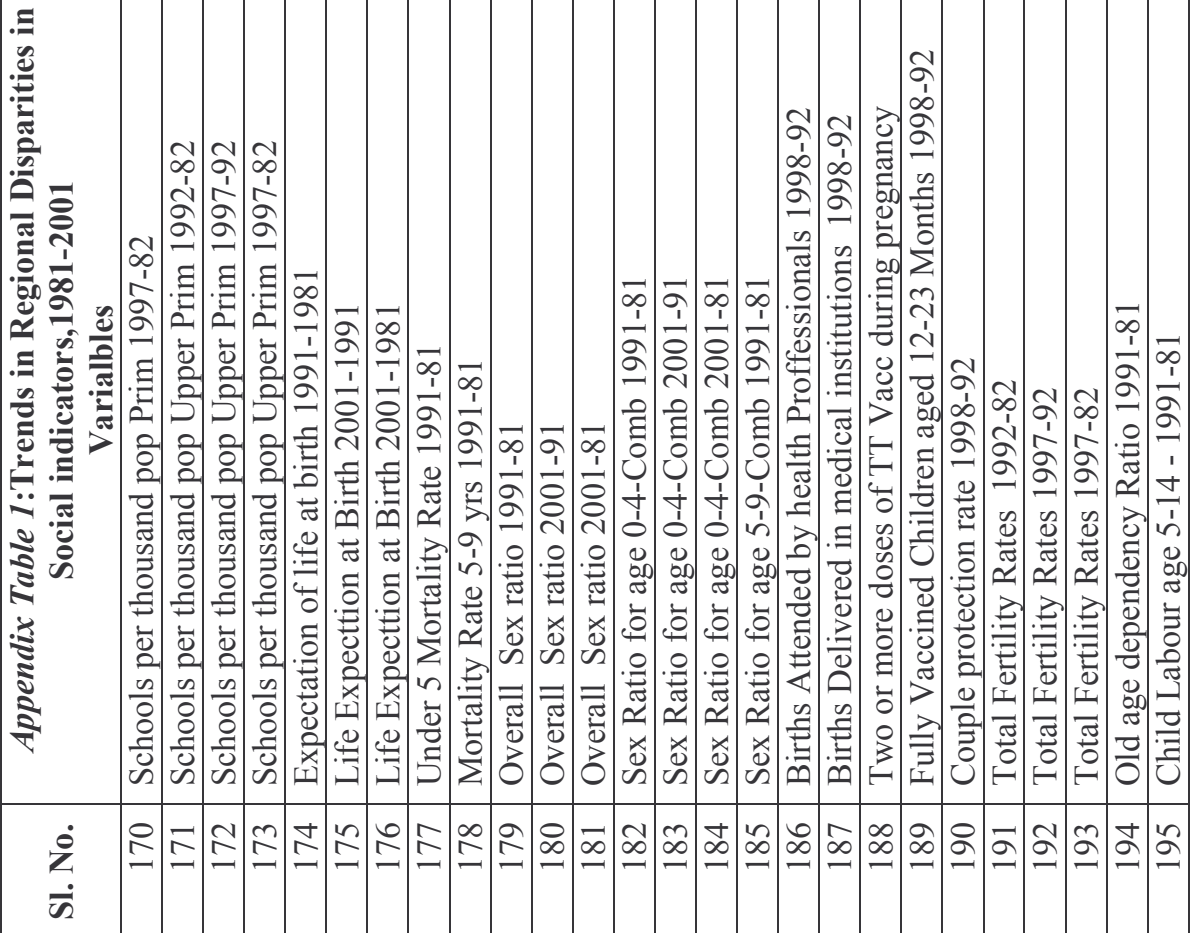

